\title{
Paenibacillus harenae sp. nov., isolated from desert sand in China
}

\author{
Che Ok Jeon, ${ }^{1}$ Jee-Min Lim, ${ }^{2}$ Seung Sik Lee, ${ }^{3}$ Bok Sil Chung, ${ }^{1,3}$ \\ Dong-Jin Park, ${ }^{2}$ Li-Hua Xu, ${ }^{4}$ Cheng-Lin Jiang ${ }^{4}$ and Chang-Jin Kim ${ }^{2}$ \\ ${ }^{1}$ Department of Life Science, Chung-Ang University, Seoul 156-756, Republic of Korea \\ ${ }^{2}$ Korea Research Institute of Bioscience and Biotechnology, 52 Oeundong, Yusong, Daejeon 305- \\ 333, Republic of Korea \\ ${ }^{3}$ Environmental Biotechnology National Core Research Center, Gyeongsang National University, \\ Jinju 660-701, Republic of Korea \\ ${ }^{4}$ Yunnan Institute of Microbiology, Yunnan University, Kunming, Yunnan 650091, PR China
}

Correspondence Chang-Jin Kim changjin@kribb.re.kr

\begin{abstract}
A Gram-positive, endospore-forming, rod-shaped bacterium, designated strain $B 519^{\top}$, was isolated from a desert sand sample of Gansu Province, China. Strain B519 ${ }^{\top}$ was strictly aerobic and cells were motile by means of peritrichous flagella. The strain grew optimally at $32-35{ }^{\circ} \mathrm{C}$ and $\mathrm{pH}$ 6.5-7.0. Chemotaxonomic data supported the affiliation of the new isolate to the genus Paenibacillus, including menaquinone-7 (MK-7) as the major isoprenoid quinone, DNA G + C content of $49.9 \mathrm{~mol} \%$, cell-wall type $\mathrm{A} 1 \gamma$ (meso-diaminopimelic acid as the diagnostic diamino acid) and anteiso- $C_{15: 0}$, iso- $C_{15: 0}, C_{16: 0}$ and iso- $C_{16: 0}$ as the major fatty acids. Comparative 16S rRNA gene sequence analysis showed that strain $B 519^{\top}$ was most closely related to Paenibacillus alkaliterrae KSL-134 ${ }^{\top}$ (98.0\% similarity). DNA-DNA relatedness between strain $\mathrm{B} 519^{\top}$ and $P$. alkaliterrae $\mathrm{KSL}-134^{\top}$ was about $12.3 \%$. On the basis of phenotypic characteristics and molecular properties, strain $B 519^{\top}$ is considered to represent a novel species of the genus Paenibacillus, for which the name Paenibacillus harenae sp. nov. is proposed. The type strain is $B 519^{\top}\left(=\right.$ KCTC $3951^{\top}=$ DSM $\left.16969^{\top}\right)$.
\end{abstract}

The genus Paenibacillus was delineated from members of Bacillus group 3 on the basis of $16 \mathrm{~S}$ rRNA gene sequence analysis by Ash et al. (1993). Since the description of the genus, species belonging to the genus Paenibacillus have been isolated from various ecological habitats, including warm springs (Saha et al., 2005; Chou et al., 2007), alkaline soils (Yoon et al., 2005), petroleum-hydrocarbon-contaminated sediment (Daane et al., 2002), the surface of sterilized seeds of garden peas (Šmerda et al., 2005), Antarctic sediments (Montes et al., 2004), the rhizosphere of trees (Rivas et al., 2005; Sánchez et al., 2005; Park et al., 2007; Yoon et al., 2007) and desert sand (Lim et al., 2006). Here we describe the taxonomic characterization of a novel aerobic, mesophilic, Gram-positive Paenibacillus species isolated from desert sand.

Strain B519 ${ }^{\mathrm{T}}$ was isolated on R2A agar (Difco) at $30{ }^{\circ} \mathrm{C}$ for 3 days from a desert sand sample from Gansu Province,

The GenBank/EMBL/DDBJ accession number for the $16 \mathrm{~S}$ rRNA gene sequence of strain B519 ${ }^{\top}$ is $A Y 839867$.

A transmission electron micrograph showing the general morphology of negatively stained cells of strain B519 ${ }^{\top}$ and extended $16 \mathrm{~S}$ rRNA gene sequence-based neighbour-joining and maximum-parsimony trees are available as supplementary material with the online version of this paper.
China. Subcultivation was done on R2A agar at $32{ }^{\circ} \mathrm{C}$ for 2 days. Gram staining was determined by using the bioMérieux Gram stain kit according to the manufacturer's instructions. Cell morphology and motility were studied by using phase-contrast microscopy and transmission electron microscopy (JEM-1010; JEOL) as described by Jeon et al. (2005). Endospores were stained according to the Schaeffer-Fulton method (Smibert \& Krieg, 1981). Physiological characteristics of the isolate were examined by cultivation on R2A medium at different temperatures and $\mathrm{pH}$ values (Gomori, 1955). Requirement for and tolerance of $\mathrm{NaCl}$ were determined in $\mathrm{R} 2 \mathrm{~A}$ medium supplemented with $\mathrm{NaCl}$. Oxidase activity was tested by oxidation of $1 \%(\mathrm{w} / \mathrm{v})$ tetramethyl-p-phenylenediamine (Merck). Catalase activity was determined by production of oxygen bubbles in $3 \%(\mathrm{v} / \mathrm{v})$ aqueous hydrogen peroxide solution. Hydrolysis of aesculin, casein, hypoxanthine, starch, Tween 80, L-tyrosine, xanthine and urea was determined on R2A according to the methods of Lányí (1987) and Smibert \& Krieg (1994). Nitrate reduction was determined according to the method of Lányí (1987). Acid production from carbohydrates was tested as described by Leifson (1963). Utilization of substrates as sole carbon and energy sources was tested as described by Baumann \& 
Baumann (1981), with each substrate supplemented with $2 \%$ (v/v) Hunter's mineral base (Cohen-Bazire et al., 1957) and $1 \%(\mathrm{v} / \mathrm{v})$ vitamin solution (Staley, 1968). Additional enzyme activities were determined by using the API ZYM (bioMérieux) system at $32{ }^{\circ} \mathrm{C}$. On R2A agar, strain B519 ${ }^{\mathrm{T}}$ formed sticky, glistening, translucent, raised and circular/ slightly irregular colonies when grown at $32{ }^{\circ} \mathrm{C}$ for 2 days. Growth was observed at $10-40{ }^{\circ} \mathrm{C}$, with optimum growth at $32-35{ }^{\circ} \mathrm{C}$. The strain grew at $\mathrm{pH}$ 6.0-10.0 (optimum growth at $\mathrm{pH}$ 6.5-7.0). Cells of the new isolate were rodshaped (width of $0.8-1.2 \mu \mathrm{m}$ and length of $2.5-3.5 \mu \mathrm{m}$ ) that were motile by means of peritrichous flagella (see Supplementary Fig. S1 in IJSEM Online). Strain B519 grew on R2A medium with the addition of $0-3 \%(w / v)$ $\mathrm{NaCl}$; optimum growth occurred on R2A without the addition of $\mathrm{NaCl}$. The isolate produced an ellipsoidal terminal endospore in a swollen sporangium. No growth was observed under anaerobic conditions after 7 days at $32{ }^{\circ} \mathrm{C}$ on $\mathrm{R} 2 \mathrm{~A}$.

Analysis of fatty acid methyl esters of strain $\mathrm{B} 519^{\mathrm{T}}$ and reference strains was performed according to the instructions of the Microbial Identification System (MIDI; Microbial ID, Inc.) after cultivation for 2 days on R2A agar. Preparation of cell walls from strain $\mathrm{B} 519^{\mathrm{T}}$ and analysis of the peptidoglycan were carried out by using the methods described by Schleifer (1985), with the modification that TLC was performed on cellulose sheets rather than paper chromatography. Isoprenoid quinones were analysed according to Komagata \& Suzuki (1987). The DNA $\mathrm{G}+\mathrm{C}$ content of strain $\mathrm{B} 519^{\mathrm{T}}$ was determined by HPLC according to the method of Tamaoka \& Komagata (1984), with the chromatograph fitted with a reversedphase column (GROM-SIL 100 ODS-2FE; GROM). The fatty acid profile of the strain was characterized as containing saturated fatty acids such as anteiso- $\mathrm{C}_{15: 0}$ $(41.1 \%)$, iso- $\mathrm{C}_{15: 0}(12.4 \%), \mathrm{C}_{16: 0}(11.6 \%)$ and iso- $\mathrm{C}_{16: 0}$ $(10.1 \%)$ as the major components; its fatty acid profile resembles those of related Paenibacillus species (Table 1). The major respiratory lipoquinone of strain $B 519^{\mathrm{T}}$ was menaquinone-7 (MK-7). Analysis of the cell-wall peptidoglycan indicated that it was of the A1 $\gamma$ type, i.e. mesodiaminopimelic acid as the diagnostic diamino acid. The genomic DNA G $+\mathrm{C}$ content of strain $\mathrm{B} 519^{\mathrm{T}}$ was 49.9 mol\%. Typical phenotypic characteristics of strain $\mathrm{B} 519^{\mathrm{T}}$ are summarized and compared with those of the type strains of closely related Paenibacillus species in Table 2. Recognized members of the genus Paenibacillus generally produce an ellipsoidal, terminal endospore in a swollen sporangium, possess anteiso- $\mathrm{C}_{15: 0}$ as the major fatty acid and have DNA G $+\mathrm{C}$ contents in the range $39-55 \mathrm{~mol} \%$ (Shida et al., 1997; Montes et al., 2004; Takeda et al., 2005). In this regard, strain $\mathrm{B} 519^{\mathrm{T}}$ possessed phenotypic characteristics typical of the genus Paenibacillus.

$16 \mathrm{~S}$ rRNA gene sequence analysis was carried out as described by Lane (1991). The resultant 16S rRNA gene sequence of strain $\mathrm{B} 519^{\mathrm{T}}$ was compared with available $16 \mathrm{~S}$ rRNA gene sequences from GenBank by using the BLAST
Table 1. Cellular fatty acid compositions of strain $B 519^{\top}$ and related members of the genus Paenibacillus

Strains: 1, B519 ${ }^{\mathrm{T}} ; 2$ 2, P. alkaliterrae $\mathrm{KSL}-134^{\mathrm{T}}$; 3, Paenibacillus agarexedens DSM $1327^{\mathrm{T}} ; 4$, Paenibacillus agaridevorans DSM $1355^{\mathrm{T}}$. Data are expressed as percentages of total fatty acids. ND, not detected. All data are from the present study.

\begin{tabular}{|lcccc|}
\hline Fatty acid & $\mathbf{1}$ & $\mathbf{2}$ & $\mathbf{3}$ & $\mathbf{4}$ \\
\hline Straight chain & & & & \\
$\mathrm{C}_{14: 0}$ & 1.5 & 2.1 & 2.1 & 1.0 \\
$\mathrm{C}_{15: 0}$ & 4.2 & 3.5 & 5.3 & 4.7 \\
$\mathrm{C}_{16: 0}$ & 8.6 & 12.3 & 12.8 & 10.9 \\
$\mathrm{C}_{17: 0}$ & $\mathrm{ND}$ & $\mathrm{ND}$ & 2.3 & 1.3 \\
$\mathrm{C}_{18: 0}$ & $\mathrm{ND}$ & 2.9 & 1.0 & 0.8 \\
Branched & & & & \\
iso- $\mathrm{C}_{14: 0}$ & 2.6 & 3.0 & 1.5 & 5.5 \\
iso- $15: 0$ & 10.2 & 5.8 & 4.3 & 4.3 \\
anteiso-C & 49.1 & 48.4 & 46.9 & 41.7 \\
iso- $\mathrm{C}_{16: 0}$ & 13.1 & 12.7 & 11.6 & 22.5 \\
iso- $\mathrm{C}_{17: 0}$ & 4.2 & 1.9 & 5.0 & 1.9 \\
anteiso-C $17: 0$ & 5.5 & 4.5 & 7.3 & 4.4 \\
Unsaturated & & & & \\
$\mathrm{C}_{16: 1} \omega 11 c$ & 0.9 & 1.3 & $\mathrm{ND}$ & $\mathrm{ND}$ \\
$\mathrm{C}_{16: 1} \omega 7 c$ alcohol & $\mathrm{ND}$ & $\mathrm{ND}$ & $\mathrm{ND}$ & 0.9 \\
Hydroxy & & & & \\
$\mathrm{C}_{16: 0} 2-\mathrm{OH}$ & $\mathrm{ND}$ & 1.7 & $\mathrm{ND}$ & $\mathrm{ND}$ \\
\hline
\end{tabular}

program (http://www.ncbi.nlm.nih.gov/BLAST/) and gene sequences were aligned with those of closely related species by using the CLUSTAL $\mathrm{W}$ software program (Thompson et al., 1994). Phylogenetic trees were constructed according to three different methods, the neighbour-joining, maximum-likelihood and maximum-parsimony algorithms available in the PHYLIP program, version 3.6 (Felsenstein, 2002). The resultant tree topologies were evaluated by bootstrap analyses based on 1000 resamplings of the neighbour-joining and maximum-parsimony data in the PHYLIP package. By using the FASTA3 program (http:// www.ebi.ac.uk/Tools/fasta33/), 16S rRNA gene sequence similarity calculations were made between strain $\mathrm{B} 519^{\mathrm{T}}$ and the type strains of other members of the Paenibacillaceae. DNA-DNA hybridization was carried out to evaluate levels of genomic DNA-DNA relatedness between strain B519 and Paenibacillus alkaliterrae KSL-134 ${ }^{\mathrm{T}}$ according to the fluorometric microplate method (Ezaki et al., 1989). Fluorometric data recorded after $30 \mathrm{~min}$ of incubation were used for calculation of levels of DNA-DNA relatedness. The highest and lowest values in each sample were excluded and the remaining three values were used for calculation of the mean level of DNA-DNA relatedness.

The almost-complete 16S rRNA gene sequence (1523 nt) of strain B519 $9^{\mathrm{T}}$ was obtained and was used for initial BLAST searches in GenBank and for phylogenetic analysis. Phylogenetic analyses based on 16S rRNA gene sequences by using the neighbour-joining and maximum-parsimony methods showed that strain $\mathrm{B} 519^{\mathrm{T}}$ formed a cluster with $P$. 
Table 2. Characteristics of strain $B 519^{\top}$ and related members of the genus Paenibacillus

Strains: $1, \mathrm{~B} 519^{\mathrm{T}}$ (data from the present study); 2, P. alkaliterrae KSL-134 ${ }^{\mathrm{T}}$ (unless indicated, data from Yoon et al., 2005); 3, P. agarexedens DSM $1327^{\mathrm{T}}$ (Uetanabaro et al., 2003); 4, P. agaridevorans DSM $1355^{\mathrm{T}}$ (van der Maarel et al., 2000). +, Positive; -, negative; $m$-DAP, mesodiaminopimelic acid; ND, no data available. All strains are positive for motility, catalase, oxidase and formation of swollen sporangia and negative for anaerobic growth, urease, indole production, nitrate reduction, the Voges-Proskauer reaction, casein hydrolysis and growth at $\mathrm{pH} 5.7$ and in the presence of $5 \%(\mathrm{w} / \mathrm{v}) \mathrm{NaCl}$.

\begin{tabular}{|c|c|c|c|c|}
\hline Characteristic & 1 & 2 & 3 & 4 \\
\hline Cell size $(\mu \mathrm{m})$ & $0.8-1.2 \times 2.5-3.5$ & $0.4-0.5 \times 1.5-3.0$ & $0.5-1.4 \times 2.0-8.0$ & $0.6-0.8 \times 2.0-5.0$ \\
\hline Colony colour ${ }^{*}$ & Whitish & Ivory & Whitish & Whitish \\
\hline Agar & - & - & + & + \\
\hline Starch & - & + & + & $(-)$ \\
\hline \multicolumn{5}{|l|}{ Utilization of: ${ }^{*}$} \\
\hline D-Mannose & + & + & - & - \\
\hline D-Xylose & + & $(-)$ & + & - \\
\hline Cell-wall type & $\mathrm{A} 1 \gamma(m-\mathrm{DAP})$ & $\mathrm{A} 1 \gamma(m-\mathrm{DAP})$ & ND & ND \\
\hline DNA $G+C$ content $(\mathrm{mol} \%)$ & 49.9 & 49.4 & 47 & 51 \\
\hline
\end{tabular}

${ }^{*}$ Data for these tests, and tests for catalase, oxidase and urease activities, indole production, nitrate reduction and casein hydrolysis, were determined in the present study. Results in parentheses are given as positive in reference sources.

alkaliterrae KSL-134 ${ }^{\mathrm{T}}$ (100 \% bootstrap support) within the genus Paenibacillus (Fig. 1; see also Supplementary Fig. S1). The topologies of phylogenetic trees built according to the maximum-likelihood and maximum-parsimony algorithms also supported the suggestion that strain $\mathrm{B} 519^{\mathrm{T}}$

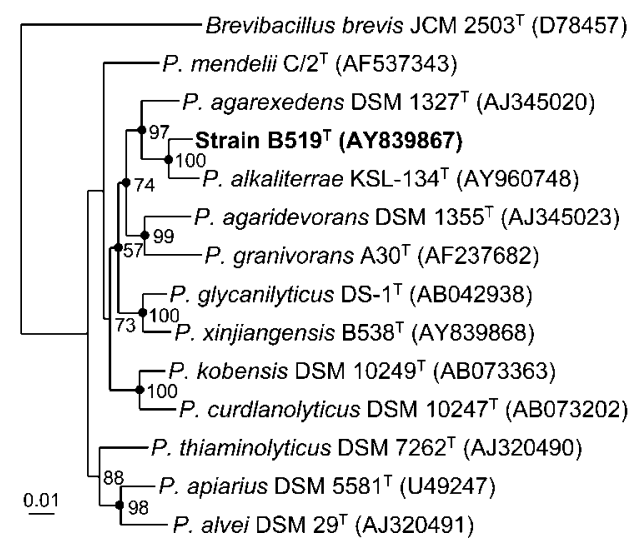

Fig. 1. Neighbour-joining tree based on $16 \mathrm{~S}$ rRNA gene sequences showing the phylogenetic relationships between strain $\mathrm{B} 519^{\top}$ and related taxa. Bootstrap values at branch points are shown as percentages of 1000 replicates; only values $>50 \%$ are shown. Filled circles indicate that the corresponding nodes were also recovered in trees generated with the maximum-likelihood and maximum-parsimony algorithms. Brevibacillus brevis JCM $2503^{\top}$ was used as an outgroup. Bar, 0.01 changes per nucleotide position. Extended neighbour-joining and maximum-parsimony trees are shown in Supplementary Fig. S1. belonged to the genus Paenibacillus (Fig. 1). The level of DNA-DNA relatedness between strain $\mathrm{B} 519^{\mathrm{T}}$ and $P$. alkaliterrae KSL-134 ${ }^{\mathrm{T}}$ was $12.3 \%$, which was clearly below the $70 \%$ threshold generally accepted for species delineation (Rosselló-Mora \& Amann, 2001; Wayne et al., 1987).

The physiological, biochemical and phylogenetic properties of strain $\mathrm{B} 519^{\mathrm{T}}$ suggest that it represents a novel species of the genus Paenibacillus, for which the name Paenibacillus harenae sp. nov. is proposed.

\section{Description of Paenibacillus harenae sp. nov.}

Paenibacillus harenae (ha.re' nae. L. gen. n. harenae of sand, referring to the isolation of the type strain from desert sand).

Cells are strictly aerobic, Gram-positive, spore-forming, motile rods. Oxidase- and catalase-positive. Nitrate is not reduced to nitrite. Grows between 10 and $40{ }^{\circ} \mathrm{C}$ (optimum $32-35{ }^{\circ} \mathrm{C}$ ) and from $\mathrm{pH} 6.0$ to 10.0 (optimum $\mathrm{pH}$ 6.57.0). Positive for esterase (C4), leucine arylamidase, acid phosphatase, naphthol-AS-BI-phosphohydrolase, $\alpha$-galactosidase, $\beta$-galactosidase and $\alpha$-fucosidase (API ZYM). Aesculin is hydrolysed, but hypoxanthine, casein, starch, Tween 80 , L-tyrosine, xanthine and urea are not. Acid is produced from D-glucose, D-fructose, D-mannitol, trehalose, $\alpha$-D-lactose, maltose, rhamnose, raffinose, inositol, sucrose, arbutin, D-salicin, melibiose, D-xylose and L-arabinose, but not from D-ribose, glycerol, adonitol or D-mannose. The cell-wall peptidoglycan is of the A1 $\gamma$ type, with meso-diaminopimelic acid as the diagnostic diamino acid. The major isoprenoid quinone is MK-7. The DNA $\mathrm{G}+\mathrm{C}$ content of the type strain is $49.9 \mathrm{~mol} \%$. 
The type strain, B519 $\left(=\right.$ KCTC $3951^{\mathrm{T}}=$ DSM $\left.16969^{\mathrm{T}}\right)$, was isolated from a desert sand sample from Gansu Province, China.

\section{Acknowledgements}

This work was supported by the 21C Frontier Microbial Genomics and Application Center Program, Ministry of Science \& Technology and by the Korea Foundation for International Cooperation of Science \& Technology (KICOS) through a grant provided by the Korean Ministry of Science \& Technology (MOST) in the Global Partnership Program (no. M60602000001-06E0200-00100).

\section{References}

Ash, C., Priest, F. G. \& Collins, M. D. (1993). Molecular identification of rRNA group 3 bacilli (Ash, Farrow, Wallbanks and Collins) using a PCR probe test. Proposal for the creation of a new genus Paenibacillus. Antonie van Leeuwenhoek 64, 253-260.

Baumann, L. \& Baumann, P. (1981). The marine Gram-negative eubacteria; genera Photobacterium, Beneckea, Alteromonas, Pseudomonas, and Alcaligenes. In The Prokaryotes. A Handbook on Habitats, Isolation, and Identification of Bacteria, pp. 1302-1330. Edited by M. P. Starr, H. Stolp, H. G. Trüper, A. Balows \& H. G. Schlegel. Berlin: Springer.

Chou, J. H., Chou, Y. J., Lin, K. Y., Sheu, S. Y., Sheu, D. S., Arun, A. B., Young, C. C. \& Chen, W. M. (2007). Paenibacillus fonticola sp. nov., isolated from a warm spring. Int J Syst Evol Microbiol 57, 1346-1350.

Cohen-Bazire, G., Sistrom, W. R. \& Stanier, R. Y. (1957). Kinetic studies of pigment synthesis by nonsulfur purple bacteria. J Cell Comp Physiol 49, 25-68.

Daane, L. L., Harjono, I., Barns, S. M., Launen, L. A., Palleron, N. J. \& Haggblom, M. M. (2002). PAH-degradation by Paenibacillus spp. and description of Paenibacillus naphthalenovorans sp. nov., a naphthalene-degrading bacterium from the rhizosphere of salt marsh plants. Int J Syst Evol Microbiol 52, 131-139.

Ezaki, T., Hashimoto, Y. \& Yabuuchi, E. (1989). Fluorometric deoxyribonucleic acid-deoxyribonucleic acid hybridization in microdilution wells as an alternative to membrane filter hybridization in which radioisotopes are used to determine genetic relatedness among bacterial strains. Int J Syst Bacteriol 39, 224-229.

Felsenstein, J. (2002). PHYLIP (phylogeny inference package), version 3.6a. Distributed by the author. Department of Genome Sciences, University of Washington, Seattle, USA.

Gomori, G. (1955). Preparation of buffers for use in enzyme studies. Methods Enzymol 1, 138-146.

Jeon, C. O., Lim, J. M., Lee, J. M., Xu, L. H., Jiang, C. L. \& Kim, C. J. (2005). Reclassification of Bacillus haloalkaliphilus Fritze 1996 as Alkalibacillus haloalkaliphilus gen. nov., comb. nov. and the description of Alkalibacillus salilacus sp. nov., a novel halophilic bacterium isolated from a salt lake in China. Int J Syst Evol Microbiol 55, 1891-1896.

Komagata, K. \& Suzuki, K. (1987). Lipid and cell-wall analysis in bacterial systematics. Methods Microbiol 19, 161-207.

Lane, D. J. (1991). 16S/23S rRNA sequencing. In Nucleic Acid Techniques in Bacterial Systematics, pp. 115-175. Edited by E. Stackebrandt \& M. Goodfellow. Chichester: Wiley.

Lányí, B. (1987). Classical and rapid identification methods for medically important bacteria. Methods Microbiol 19, 1-67.

Leifson, E. (1963). Determination of carbohydrate metabolism of marine bacteria. J Bacteriol 85, 1183-1184.
Lim, J.-M., Jeon, C. O., Lee, J.-C., Xu, L. H., Jiang, C. L. \& Kim, C.-J. (2006). Paenibacillus gansuensis sp. nov., isolated from desert soil of Gansu Province in China. Int J Syst Evol Microbiol 56, 2131-2134.

Montes, M. J., Mercade, E., Bozal, N. \& Guinea, J. (2004). Paenibacillus antarcticus sp. nov., a novel psychrotolerant organism from the Antarctic environment. Int J Syst Evol Microbiol 54, 15211526.

Park, M. J., Kim, H. B., An, D. S., Yang, H. C., Oh, S. T., Chung, H. J. \& Yang, D. C. (2007). Paenibacillus soli sp. nov., a xylanolytic bacterium isolated from soil. Int J Syst Evol Microbiol 57, 146-150.

Rivas, R., Gutierrez, C., Abril, A., Mateos, P. F., Martinez-Molina, E., Ventosa, A. \& Velazquez, E. (2005). Paenibacillus rhizosphaerae sp. nov., isolated from the rhizosphere of Cicer arietinum. Int J Syst Evol Microbiol 55, 1305-1309.

Rosselló-Mora, R. \& Amann, R. (2001). The species concept for prokaryotes. FEMS Microbiol Rev 25, 39-67.

Saha, P., Mondal, A. K., Mayilraj, S., Krishnamurthi, S., Bhattacharya, A. \& Chakrabarti, T. (2005). Paenibacillus assamensis sp. nov., a novel bacterium isolated from a warm spring in Assam, India. Int J Syst Evol Microbiol 55, 2577-2581.

Sánchez, M. M., Fritze, D., Blanco, A., Sproer, C., Tindall, B. J., Schumann, P., Kroppenstedt, R. M., Diaz, P. \& Pastor, F. I. (2005). Paenibacillus barcinonensis sp. nov., a xylanase-producing bacterium isolated from a rice field in the Ebro River delta. Int J Syst Evol Microbiol 55, 935-939.

Schleifer, K. H. (1985). Analysis of the chemical composition and primary structure of murein. Methods Microbiol 18, 123-156.

Shida, O., Takagi, H., Kadowaki, K., Nakamura, L. K. \& Komagata, K. (1997). Transfer of Bacillus alginolyticus, Bacillus chondroitinus, Bacillus curdlanolyticus, Bacillus glucanolyticus, Bacillus kobensis, and Bacillus thiaminolyticus to the genus Paenibacillus and emended description of the genus Paenibacillus. Int J Syst Bacteriol 47, 289-298.

Šmerda, J., Sedláček, I., Páčová, Z., Durnová, E., Smíšková, A. \& Havel, L. (2005). Paenibacillus mendelii sp. nov., from surfacesterilized seeds of Pisum sativum L. Int J Syst Evol Microbiol 55, 23512354.

Smibert, R. M. \& Krieg, N. R. (1981). General characterization. In Manual of Methods for General Microbiology, pp. 409-443. Edited by P. Gerhardt, R. G. E. Murray, R. N. Costilow, E. W. Nester, W. A. Wood, N. R. Krieg \& G. B. Phillips. Washington, DC: American Society for Microbiology.

Smibert, R. M. \& Krieg, N. R. (1994). Phenotypic characterization. In Methods for General and Molecular Bacteriology, pp. 607-654. Edited by P. Gerhardt. Washington, DC: American Society for Microbiology.

Staley, J. T. (1968). Prosthecomicrobium and Ancalomicrobium: new prosthecate freshwater bacteria. J Bacteriol 95, 1921-1942.

Takeda, M., Suzuki, I. \& Koizumi, J. (2005). Paenibacillus hodogayensis sp. nov., capable of degrading the polysaccharide produced by Sphaerotilus natans. Int J Syst Evol Microbiol 55, 737-741.

Tamaoka, J. \& Komagata, K. (1984). Determination of DNA base composition by reversed-phase high-performance liquid chromatography. FEMS Microbiol Lett 25, 125-128.

Thompson, J. D., Higgins, D. G. \& Gibson, T. J. (1994). CLUSTAL W: improving the sensitivity of progressive multiple sequence alignment through sequence weighting, position-specific gap penalties and weight matrix choice. Nucleic Acids Res 22, 4673-4680.

Uetanabaro, A. P., Wahrenburg, C., Hunger, W., Pukall, R., Spröer, C., Stackebrandt, E., De Canhos, V. P., Claus, D. \& Fritze, D. (2003). Paenibacilus agarexedens sp. nov., nom. rev., and Paenibacillus agaridevorans sp. nov. Int J Syst Evol Microbiol 53, 1051-1057. 
van der Maarel, M. J. E. C., Veen, A. \& Wijbenga, D. J. (2000). Paenibacillus granivorans sp. nov., a new Paenibacillus species which degrades native potato starch granules. Syst Appl Microbiol 23, 344-348.

Wayne, L. G., Brenner, D. J., Colwell, R. R., Grimont, P. A. D., Kandler, O., Krichevsky, M. I., Moore, L. H., Moore, W. E. C., Murray, R. G. E. \& other authors (1987). International Committee on Systematic Bacteriology. Report of the ad hoc committee on reconciliation of approaches to bacterial systematics. Int J Syst Bacteriol 37, 463-464.

Yoon, J.-H., Kang, S.-J., Yeo, S.-H. \& Oh, T.-K. (2005). Paenibacillus alkaliterrae sp. nov., isolated from an alkaline soil in Korea. Int J Syst Evol Microbiol 55, 2339-2344.

Yoon, M. H., Ten, L. N. \& Im, W. T. (2007). Paenibacillus ginsengarvi sp. nov., isolated from soil from ginseng cultivation. Int $J$ Syst Evol Microbiol 57, 1810-1814. 